American Journal of Art and Design
2021;6(3): $84-94$
http://www.sciencepublishinggroup.com/j/ajad
doi: 10.11648 /j.ajad.20210603.13
ISSN: $2578-7799$ (Print); ISSN: $2578-7802$ (Online)

\title{
A Journey of the Soul: Catharsis and Salvation in the Mosaic of Casaranello (Italy, 6th Century)
}

\author{
Francesco Danieli \\ Gli Argonauti, Roman University Editions, Rome, Italy
}

\author{
Email address: \\ cicciodanieli@gmail.com
}

\section{To cite this article:}

Francesco Danieli. A Journey of the Soul: Catharsis and Salvation in the Mosaic of Casaranello (Italy, 6th Century). American Journal of Art and Design. Vol. 6, No. 3, 2021, pp. 84-94. doi: 10.11648/j.ajad.20210603.13

Received: June 12, 2021; Accepted: July 19, 2021; Published: July 28, 2021

\begin{abstract}
The church of Santa Maria della Croce in Casaranello (Casarano, Italy, 6th century) is an important paleoByzantine testimony in Southern Italy. The building is well preserved and corresponds more or less to its original structure because in the late-medieval age the community of Casaranum decided to move the residential area up the hill overlooking the original hamlet. The German art historian Arthur Haseloff (1872-1955) visited the church in 1907, intrigued by a bibliographic indication by Wladimir De Gruneisen, and he found it in the miserable condition of stall for sheep and goats. When he entered the church, he immediately realised he was in front of one of the most important jewels of the paleochristian art: a treasure fallen into oblivion and whose value deserved to be highlighted. Haseloff summarily analysed the site of Casaranello, paying particular attention to the mosaic. This research promoted a new awareness towards Santa Maria della Croce and laid the basis for the restoration interventions carried out during the second half of the ' $900 \mathrm{~s}$. In particular, the restoration and preservation interventions performed between 1971 and 1979 outlined new guidelines for the study of the building and its artistic heritage. In 2018 the writer of this essay published a new interpretation of the mosaic of Casaranello for the Esperidi Editions. In 2020, with Alessandro De Marco, first for Christian-Albrechts-Universität of Kiel (Germany), then for the Edizioni Universitarie Romane, he completed this research with further historical, architectural and artistic notes on the entire building. An unknown figure, depicted in fresco, has been identified as the emperor Constantine the Great, while the mosaic revealed its symbolic message: a cathartic journey of the soul per aspera ad astra.
\end{abstract}

Keywords: Casaranello, Mosaic, Byzantine Art, Iconology

\section{Introduction}

The church of Casaranello (Casarano, Italy), dedicated to Santa Maria della Croce, is one of the oldest and best preserved Paleo-Byzantine buildings in Southern Italy. Certainly, among the most important in the province of Lecce, in Puglia. The temple was built around the 5th century, but it was in the 6th century that it was enriched with a wonderful highly symbolic mosaic. For lovers of Art History and pre-Christian and Christian symbolism, Casaranello should be an essential stop on a trip to Italy.

\section{Casaranello, Unfair Nickname}

From an etymological point of view, the toponym Casaranello does not do justice to the immense cultural and artistic value of the site it refers to [1-10]. This name originates from the dialect spoken in Salento and is today a nickname referred to a district of the city of Casarano. From the late Middle Ages onwards, Casarano has expanded across the hill overlooking the original hamlet, which was founded in the late-imperial Roman age in the area surrounding the church of Santa Maria della Croce. For a long time - and to some degree, still today - not even the inhabitants of Casarano have been fully aware of the precious value of this ancient church, silent guard of magnificent wall mosaics which make it one of its kind.

In order to fully understand the hidden meaning of Casaranello's mosaic cycle and to correctly interpret its iconological message, it is fundamental to walk through the milestones marking the origins and the developments of its location. The origins of Casarano, one of the most important municipalities of the province of Lecce, have not yet been completely defined. A vague and scarcely detailed hypothesis was formulated during the Baroque age by the Capuchin Luigi 
Tasselli (1622-1694). According to him, the first to settle in loco were some fugitives from Sasina, a town of the Magna Graecia later renamed Cesàrea (which the current name of Porto Cesareo derives from). After the destruction of their city, occurred in the 5th century BC by the hands of people from Gallipoli, the fugitives allegedly escaped into the hinterland. According to this hypothesis, Caesaranum is the Latin adjective suggesting the emotional link of those fugitives with Cesàrea, their native town. This theory seems quite unlikely for the simple reason that nobody would try to escape an invader by seeking hideout near the invader's home.

According to another hypothesis, Casarano was initially founded in the 1 st century $\mathrm{BC}$ as a conurbation grown on the estates of a Roman centurion named Caesar. He supposedly received those public lands in his capacity of war veteran, as a compensation for the military campaigns he led. Such practice has been often confirmed by historical and literary sources throughout the whole late Republican age. Therefore, the village might have been named Caesaranum after that Caesar. The two Latin epigraphs Vibuleius and Musicus, found in the area of Casaranello, undoubtedly testify that already during the Roman period Casarano was a flourishing centre in the Japigian hinterland. Actually, the first human settlement in the area dates back to the prehistoric age, as testified by the toponym of the near district Specchia di Vaje. A more articulated organisation of the conurbation dates back to the Messapian period: this can be inferred by the presence of entombments (so far considered exclusively "medieval") and by small traces of calcarenite walls. These walls are still present in the area surrounding Santa Maria della Croce, nearby the railway that, together with the bridge, separates contrada Casaranello from contrada Botte.

It was a common practice among the Messapians to set up small conurbations along precise trajectories connecting the most important cities. The site of Casaranello, for example, is situated in the area corresponding to the main crossroad of Salento: the one that from Taranto and from northern Japygia, passing by Manduria, Nardò and Alezio, branched off towards Ugento, Patù, Vaste, Castro and the seaports to the East. This fortunate geographic position - confirmed in the Roman age by the construction of the Via Appia Traiana and of its prolongation conventionally known as Via Augusta Sallentina - fostered for centuries the transit of men, goods and different cultures. This is the main reason for the existence of such refined and meaningful mosaics in a sacred building - only apparently similar to many others - in the periphery of the Regio Secunda of the Roman Empire.

\section{Casaranello and the Spreading of Christianity}

Whereas we have a wide literary and archaeological evidence of the spreading of Christianity in northern Apulia (Canosa, Bari, Egnazia, Erdonia), the sources of the Christianisation of Salento are very scarce [11-21]. In his Apologia contra Arianos, Athanasius of Alexandria mentions the anti-Arian bishops who took part with him in the Synod of Serdica in 343, among whom there were colleagues coming "ex Apulia et Calabria". It is important to consider that in the imperial geographical- administrative division, Apulia and Calabria constituted in solido the Regio Secunda. Apulia corresponded to the current central and northern Apulia, whereas Calabria was the current Terra d'Otranto. The region today known as Calabria, on the other hand, was at the time known as Brutium. Athanasius' clarification is highly relevant, because it confirms that from the first half of the 4th century, from an ecclesiastic point of view, the Japygian territory was organised in dioceses, each one guided by a bishop. His indication also testifies that even in the districts of Salento the theological debate used to be very lively, especially regarding the Arian disputes over the two natures - human and divine - of Christ.

The rural parish church of Casaranello was founded about two centuries later, around $550 \mathrm{AD}$, in the sphere of influence of the long-established diocese of Gallipoli, remaining the first and most important surviving Christian evidence in southern Apulia. About one century earlier, in the ecumenical council of Ephesus held in 431, Mary of Nazareth had been once and for all officially recognised and celebrated as the Mother of God, in spite of Nestorius' thesis. Meanwhile, on the secular scenario, the Western Roman Empire was collapsing under the burden of maladministration and barbaric invasions.

\section{The Salvation of Casaranello}

It was not people's awareness of the architectural heritage what saved the church of Santa Maria della Croce from destruction and allowed it to survive almost untouched until today. The preservation of cultural heritage is a modern concept; it was almost totally absent in the ancient times until Renaissance, at least until the stances of Cesare Baronio (1538-1607), who can be considered its first real initiator. Previously, civil and religious buildings used to be destroyed, expanded, simplified and re-embellished - with the help of a handful of pragmatism and ergonomics - according to the trends of the moment and the requirements of the owners or the community.

Therefore, the church of Casaranello would have ceased to exist long ago if only the people of Casarano had wanted to substantially expand it, in order to adapt its structure to the growing population. On the contrary, the building is well preserved and corresponds more or less to its original structure because in the late-medieval age the community decided to move the residential area up the hill overlooking the original hamlet. This happened at different stages, until its total abandon in the ' 800 s, as testified by: the realisation of out-ofcycle frescoes in the mid-16 th century; the fusion of two bells (which got stolen in 2002) at the hands of the craftsmen Patitari from Gallipoli in 1555; the erection of a Baroque machine made of Lecce limestone for the high altar (dismantled and demolished in the '900s); and the attention paid to the temple by Antonio Sanfelice, bishop of Nardò. In 1717 , Sanfelice commissioned the placement of an epigraph in 
memory of the presumed birth in Casarano of Pope Boniface 9th (1389-1404), who was allegedly baptised within these walls.

The progressive move of the population from the old Casarano to the new conurbation, much bigger and better organised than the original one, was a consequence of two necessities: first, the enjoyment of a better wholesomeness uphill, away from the marshlands present on the slopes, where the stings of insects and mosquitoes could transmit horrible diseases such as malaria; second, the need to ensure a stronger defence of the community through faster enemy sighting systems: this was an effect of the recurrent pirate incursions, which afflicted the coasts and the hinterland of Salento, especially between the end of the Middle Ages and the beginning of the Modern Ages.

However, the first conurbation of Casarano continued to be inhabited, as proven by some registries documenting a census of 1.100 inhabitants in 1414. This made it necessary to split the denomination into Casaranum Parvum (Little Casarano) and Casaranum Magnum (Big Casarano), as testified since 1272 in the 8th volume of the Registri della Cancelleria Angioina. The macaronic latinisation of Casaranellum was already in use during the Baroque period, as confirmed by Antonio Chetry, a Jesuit priest from Casarano (1913-1984), who found this information in some manuscripts from the '600s.

\section{Rediscovery and Promotion of Santa Maria Della Croce}

Some coeval documents provide evidence that in 1797 the number of inhabitants of Casarano dropped to only 100. In the ' $800 \mathrm{~s}$, the conurbation had definitely disappeared, downsized to less than a rural village, with a few houses $a$ cannizzu, covered by roofs made of straws and shingles. They were inhabited by families - together with their animals - devoted to the cultivation of the surrounding fields and to grazing. Even the church of Santa Maria della Croce, old parish and heart of the hamlet, was completely abandoned, interdicted to worshipping and even used as a stall.

When the German art historian Arthur Haseloff (18721955) visited the church in 1907, intrigued by a bibliographic indication by Wladimir De Gruneisen [22], he found it in the miserable condition of stall for sheep and goats. At the time, the scholar had been working for two years as a secretary in the Historic Prussian Institute of Rome and later in 1920, once back in Germany, he was nominated Professor of Art History at Kiel University. When he entered the church, he immediately realised he was in front of one of the most important jewels of the paleochristian art: a treasure fallen into oblivion and whose value deserved to be highlighted. Haseloff summarily analysed the site of Casaranello, paying particular attention to the mosaic [23]. Thanks to the publication of his studies on Santa Maria della Croce, for the first time Casarano became aware of guarding a priceless historic and artistic heritage.

Other notable experts showed great interest in this monument thanks to Haseloff, complementing his studies and adding new contributions: Renato Bartoccini in 1934 [24], Giuseppe Palumbo in 1950 [25], Adriano Prandi in 1961 [39], Margherita Maria Trinci Cecchelli in 1974 [26], Francesco D'Andria in 1976 [27], Corrado Bucci Morichi in 1983 [28], André Jacob in 1988 [29], Giorgio Spinosa in 2002 [30], Marina Falla Castelfranchi in 2004 [31] and Ginò Pisanò, also in the years 2000s [32].

This constant research promoted a new awareness towards Santa Maria della Croce and laid the basis for the restoration interventions carried out during the second half of the ' 900 s. In particular, the restoration and preservation interventions performed between 1971 and 1979 outlined new guidelines for the study of the building and its artistic heritage.

In 2018 the writer of this essay published a new interpretation of the mosaic for the Esperidi Editions [33], complemented by historical and artistic notes on the entire building. The volume, which is accompanied by unprecendented high-resolution images, found great appreciation especially in the German academic community, to the point that its author and Alessandro De Marco were invited to deliver a lectio magistralis on the subject at the University of Kiel (Germany), on the occasion of the conference for the 125th anniversary of the foundation of the Institute of Art History of that university, on October 26, 2018 [34, 35].

The same volume was boycotted by a part of the local intelligentsia, to the point that an attempt was made to put it in the shade, by the publishing of a bibliographic collection on the same subject, signed by Leo Stefàno (recently passed away) [36], which offered nothing new in the research but simply scrambled what was already in the pan, accusing the new hypotheses of being fictional. Meanwhile, only the philosopher and journalist Alberto Nutricati gave voice to the new discoveries in the local press. One had to wait until 2020 for Mario Spedicato, professor of the University of Salento and president of the Società di Storia Patria, to review the volume Casaranello and its mosaic. Per aspera ad astra in the magazine of the Department of Cultural Heritage of the University of Salento and to affirm that «l'opera di Danieli sul mosaico di Casaranello è imprescindibile per chi si ponga d'ora in avanti al cospetto di questo straordinario tesoro di storia ed arte» («Danieli's work on the mosaic of Casaranello is crucially important for anyone who, from now on, will approach this extraordinary historical and artistic treasure») [37].

\section{A Greek Cross Plan}

Marina Falla Castelfranchi determined the different phases of construction of the church of Santa Maria della Croce in a more precise manner than it was done in the past. In her remarkable 2004 study, in fact, she postponed the dating of the building to the 6th century AD. This resulted from a synthetic interpretation of the data collected during the restoration works of the " 70 s and especially of the 2000 s and from the comparison between the structure of the building of Casarano with other coeval buildings present in Terra 
d'Otranto and elsewhere. The in-depth examination of the visible parts of the walls suggested by Castelfranchi dismounted Adriano Prandi's initial thesis (1961), according to which the building was originally built with a Greek cross plant, that is with the four arms of equal length set around the barycentric cupola.

Also these details contribute to postponing the building of the church of Santa Maria della Croce to the mid-6 th century; they testify to the Byzantine origin of the building and prove that its construction followed the fashion trends of those times and the new dominators' taste, in the first decades following the Gothic war and the military campaign led by Belisario in 535. After these events, the South of Italy was divided into temi (some sort of administrative provinces) and annexed into the Eastern Roman Empire. It is therefore more appropriate to define the church of Casaranello as "paleobyzantine" rather than "paleochristian"!

The latest stratigraphic surveys, made with avant-garde techniques, however, have allowed Alessandro De Marco to determine that the building was surely built on a Greek cross plan - as the earliest researchers believed - and only later and through various techniques had been enlarged in the form of a basilica plan [38].

\section{Frescoes}

Although the frescoes are not Casaranello's main feature, they do constitute an interesting decorative equipment of the church and therefore deserve to be taken into consideration [39-45]. The most ancient ones date back to between the end of the 10th and the beginning of the 11th century. This hypothesis is also widely supported by the presence of Greek graffiti inscriptions. Such inscriptions - deciphered and dated by the Belgian palaeographer Andrè Jacob - testify to the continuous flux of pilgrims and travellers from and to the East via that district, as previously extensively explained.

These frescoes, painted along the apse's northern wall, are: The Holy Bishop (blessing and wearing the bishop pallium), identifiable as Saint Nicholas of Myra, and the "Holy" Emperor (holding a cross and a crown), recently identified by the author of this volume as (St.) Constantine the Great [46].

On the nave's last left pillar, the Vergine Theotókos Hodegetria is depicted in the most genuine byzantine impassivity, while she, Mother of God, shows Baby Jesus as the only possible road to salvation.

On the corresponding right pillar (last one on the right) the wonderful Saint Barbara is wrapped in the luxury clothes typically worn by the high-ranked women in the imperial court of Byzantium, adorned with buckles, pearl crowns and gems. She wears a precious set of pending earrings and a nose ring and holds the martyr cross in her right fist.

Saint Michael the Archangel symbolises the mitigation of the political contrast between the Byzantines and the Longobards which venerated him as main patron saint - and the religious and cultural contact between these two peoples. He holds the spear in his right hand and the shield in his left hand.

Saint Parascheva, also known as Santa Venerdia or Santa
Venere, is today placed in the counter-façade; she is the personification of the Passion of Jesus Christ; its iconography derives from the Roman Parca Àtropo, who cuts the thread of life from a roll symbolising existence. Actually, one can identify an even more ancient layer of frescoes, whose fragments can be glimpsed under the apse's paintings.

The frescoes on the first layer of the nave's barrel vault were performed at a later stage. They date back to the 12 th century and constitute the so-called Christological cycle, which was originally divided into twelve main episodes of the Redeemer's life. Some episodes of the Passion are still visible, oddly placed counterclockwise: on the left, in correspondence with the first arch, the Last Supper and the Arrest of Jesus in the Gethsemane; on the right, the Holy Women at the Sepulchre and the Anastasis. The presence of a Christological cycle creates a link between the pictorial modernisation carried out in those years in Casaranello and the equivalent iconographic choices that can be found in San Pietro in Otranto - two centuries older - as well as the coeval paintings in San Mauro, on the hills of Altolido, in Sannicola.

The two-party martyrial cycle above the Christological cycle is even more recent: it depicts the passiones of Saint Catherine of Alexandria (on the left) and Margaret of Antioch (on the right). According to Pierluigi Leone de Castris (1986) their execution dates back to the late Swebian age, in the exact half of the 13th century. The dynamism of the scenes marked by a modern 'slides' style, and the explanation of those slides through captions, provide ancient and modern observers with a compendium of the feminine heroic virtues - far from being taken for granted in a sexist context characterising society already in those times.

The paintings carried out in different phases during the following centuries deserve a separate consideration: an atypical Deesis ("supplication", "intercession") from the '200s, with Master Jesus accompanied by the Virgin at his right and John the Baptist at his left - in Casaranello with an additional inscription of John the Evangelist.

The remains of a Suffering Christ Bridegroom (Imago pietatis) and of a Madonna with Child - both from the late '300s - as well as Saint Nicholas of Myra and Theotókos, above the last left pillar.

The wonderful Madonna with the Child - Meter Theou authentic Madonna of Casaranello, today placed on the right side of the door leading into the sacristy. Until the restoration at the beginning of the ' 900 s it was placed at the centre of the aforementioned baroque high altar, which was later destroyed. Baby Jesus softly touches with his right hand his Mother's right hand, while holding in his left hand the papyrus containing Isaiah's messianic prophecy 61,1 («The Spirit of the Lord God is upon me; because the Lord hath anointed me to preach good tidings unto the meek; he hath sent me to bind up the broken-hearted, to proclaim liberty to the captives, and the opening of the prison to them that are bound»). The Child's gesture makes the painting a variation of Hodegetria, more precisely the Gorgoepikoos («the one who grants somebody's wish»), based on the model of the image worshipped in the monastery of Docheiariou on 
Mountain Athos. This late Byzantine icon (end of 14th century) was worshipped for centuries as patron of the temple and, according to the French iconographer Michel Berger, it was executed by the same painter who decorated the apse of Santo Stefano in Soleto.

The portrait of Pope Urban 5th (1362-1370) dates back to the late $300 \mathrm{~s}$. He is depicted holding in his hands the tray with the heads of the apostles Peter and Paul, in memory of the transfer of those famous relics to San Giovanni in Laterano, upon request of that Pope on 16 April 1369. He is dressed in the papal vestments and wears a papal tiara with one single crown, according to the archaic model, although Boniface 8th (1294-1303) had already added the second crown and Clement 5th (1305-1314) had added the third one. Therefore, at the time of Urban 5th, the papal tiara already used to be the triregnum: symbol of the ecclesiastic, spiritual and secular power of the Pope, universally renowned as the "father of princes and kings, leader of the world, Vicar of Christ on Earth". The single crown on Urban 5 th 's head, in Casaranello, brings into focus the spiritual prerogative stressed by this Pope, who overcame political and personal interests and unsuccessfully attempted to move the Apostolic See from Avignon back to Rome. Urban 5th is framed in a gothic recess; a golden beamy nimbus places him among those who were beatified, although his beatification was proclaimed by Pius 9th only five centuries after the realisation of the fresco, in 1870 .

The fragments of the images of Saint Dominic of Guzman and Saint Bernardino of Siena, with his distinctive Christological trigraph IHS ("Iesus hominum salvator" - "Jesus saviour of all men"), can be traced back to the late "400s. They recall the importance of the Mendicant orders in late medieval and modern Salento and of their influence in the elimination of the Byzantine nature of the Christians of Terra d' Otranto.

The diptych containing the portraits of Saint Anthony the Abbot and Saint Eligius, dating back to 1538, testifies to a very important social factor: in those years Casaranello was already a suburb of the overlooking Casarano Grande and its inhabitants dedicated themselves to the husbandry of pets and stable animals - which the two saints are considered protectors of - and to the related blacksmithing activity. In fact, at the feet of the Saint Bishop of Noyon, an anvil, a hammer, some nails and a horseshoe are portrayed.

The Nursing Madonna, who gives salvation to the souls together with Baby Jesus, dates back to the ' 600 s and has a lower artistic value, although it is very valuable on the iconological level. The fresco, which dates back to 1643 , is placed inside, next to the lateral door on the north side.

\section{The Mosaic: A Journey of the Soul}

What makes the church of Santa Maria della Croce one of its kind is not its architectural structure, nor its ornamental frescoes: it is the mosaic. Realised through the skilful juxtaposition of vitreous and marble tiles, it dates back to after the construction of the building, within the second half of the 6th century. According to De Gruneisen (1906), the mosaic was executed by craftsmen in transit, coming from Ephesus in Asia Minor, landed in Otranto and directed to Ravenna to realise the well-known mosaic cycles. Such hypothesis should not be underestimated, since there are evident stylistic and chromatic analogies between the mosaics of Casaranello and the floor mosaic covering Curetes Street in Ephesus. Numerous analogies can also be found with the mosaics of the archaeological park of Nea Paphos in Cyprus, especially regarding the polychrome and polymorphous strips. The mosaic of Santa Maria della Croce is characterised by wonderful colours and is even more fascinating thanks to its hidden iconological message, but so far it has been only partially interpreted.

\section{From an Iconographic to an Iconological Interpretation}

Marina Falla Castelfranchi (2004), rebutting in a not so veiled manner to the interpretation by Gino Pisanò (2003), states that $\ll(\ldots)$ the decoration of the barrel vault seems to answer primarily to ornamental needs, with only generic hints to the Christ-Fish and the paradisiacal environment», while «there is no doubt on the fact that the cupola's decoration answers to symbolic and theological requirements»».

Gino Pisanò (1947-2013), professor and scholar from Casarano, was the first to try and give an exegetical interpretation of the mosaic. He glimpsed a depiction of the Garden of Eden in the intrados of the apse's barrel vault and a depiction of Heaven in the intrados of the cupola. The interpretation of the zoomorphic and phytomorphic elements present in the artwork was also weak, as they were too loosely defined as guests of the «garden of God», the «paradeison». In order to be fully understood, not only do these elements need a thorough historical and artistic knowledge, but they also require a holistic theological and symbolic understanding: fundamentally, an iconological interpretation [47-102].

\section{The Jellyfish as Interpretation Key}

The key to the interpretation of the whole mosaic of Santa Maria della Croce is the life cycle of the jellyfish, depicted on the four pinnacles tranferring the weight of the cupola onto the presbytery's load-bearing walls. According to the current zoological terminology, the jellyfish is a planktonic, mostly marine, animal. It belongs to the Cnidaria phylum and is included, together with the Ctenophora, among the living beings once called Coelenterata. Recent study shows that there is a particular jellyfish which is potentially immortal, because it rejuvenates with the time until it begins a new life cycle. Although there was no such scientific knowledge at the time when the mosaics were realised, in Casaranello the jellyfish is used to symbolise the soul of the believer. Its transparency recalls incorporeality and immateriality. It is placed next to twigs entangled in spirals, creating a crown of solar swastikas. An explosion of pomegranates, grapes, pears, figs and various fruits enriches the composition, whereas the 
decorations decline downwards, culminating on all four pinnacles in a big fig leaf. All these elements allude to the perpetual cyclic nature of life, the constant succession of the seasons and the cosmic becoming.

The life cycle of the jellyfish is an actual literary inclusion inside Casaranello's mosaic. It is the nucleus of the entire scenographic and communicative framework, placed between the presbytery's barrel vault, where the soul is symbolised in its corporeity and materiality, and the cupola's vault, where the soul is completely absorbed by the divine. An actual chiasmus, in which even the ascensional architecture of the ribbed pinnacles indicates the ambition of the soul to free itself from every terrestrial element in order to transcend and fully relish the immortality of God.

\section{A Compendium of Greek Philosophy and Hebraic Talmud}

From the many details hidden in the artwork one can deduct that both those who commissioned the artwork and the artists of Casaranello were very familiar with the Greek philosophy. Working in the anti-gnostic and anti-arian context of the small Christian community of Casaranum in the 6th century, they chose to represent a theology of the Logos (Word of God, Christ) through a symbolic itinerary that exposes its saving action upon the believers, followed by the catharsis of the soul and its liberation from materiality. A big part of the PreSocratic philosophy has been Christianised in Casaranello, in particular Heraclitus (535-475 AD): the Logos is the supreme principle of nature, organising it through rational laws; the Christ-Logos is the rationality immanent to nature itself and the only source of rationality for men. This concept was glorified by Plato to such an extent to believe that only through Logos it is possible to reach the highest form of knowledge: the ideas, the dialectics.

Also Empedocles' philosophy (495-430 BC) can be found in Casaranello. In the barrel vault, in fact, animals and plants are enveloped in a four-coloured stripe, correspondent to the colours of the four elements: water, air, earth and fire. According to Empedocles, the four roots (rhizai) generating every existing thing are governed by the fluctuating tension between Love and Strife. When Love is stronger (as it is the case in the mosaic), the elements blend in a homogeneous sphere and there is no conflict between them. When Strife prevails, on the other hand, the elements disintegrate in the Sphere and the matter destroys itself. It is Chaos. A new intervention by Love re-establishes the lost balance and gives new life to the matter, so that the Sphere gets back to its initial condition and the cycle begins again. In the mosaic of Santa Maria della Croce, the cyclic nature is expressed by the stripe with the circular meander.

A fifth element adds to Empedocles' four elements: the quintessence, also called etere. It is the matter of which the celestial spheres are made, the essence of the Hyperuranion, unchangeable and eternal. In our mosaic, the quintessence is depicted in the stripe decorated with rectangular parallelepipeds in a tri-dimensional perspective, immersed in the starry universe, with the number five imprinted on the anterior extremity. The number five also recurs in the gemmed stripes, which will be presented hereafter, alternating with precious stones. The parallelepiped also symbolises the Ark of the Covenant, that is the treasure chest containing the Tablets of the Mosaic Law upon which the Ten Commandments were carved. The Israelites transported the Ark for forty years during the exodus from Egypt to the Promised Land. King Salomon supposedly placed it in the Sancta Sanctorum of the Temple in Jerusalem. Its traces allegedly got lost after the destruction of the Holy.

City by the hands of the Roman army led by Tito in $70 \mathrm{AD}$. The Ark's bottom parallelepiped was made of acacia wood. The Ark's cover, on the other hand, was made of a single golden plate. For the Hebrew Talmud (ancient compendium of the rabbinic teaching and the commandments of the Torah), the symbolic allusion is to be found in the binomial earth-sky. The three distinct pieces of the chest allude to the three spatial dimensions, whereas the single cover symbolises the temporal dimension. According to the Hebraic knowledge, to this fourdimensionality of the container one should add the contained, that is the Tablets of the Law, which constitute the fifth dimension, the quintessence: the pure knowledge, the union of the human with the divine. Orally transmitted for millenniums, this mystic conception was later acknowledged and written down in the Hebraic Cabala, starting from the 12 th century AD.

\section{Reductio ad Unum and Journey of Initiation}

Also the two gemmed stripes indicate a higher level of knowledge, the passage from darkness to light, the renounce to the city of men and the choice to live in the City of God, the New Jerusalem, «all garnished with precious stones» (Apocalypse 21, 18-22). In the same way, the stripe where the Looped Square is depicted horizontally further underlines the deep union between the human sphere and the divine sphere, made possible through the incarnated Logos, Jesus Christ, Knowledge of God.

A further reference to the Greek philosophy - in particular to the Neoplatonic philosophy of the reductio ad Unum - can be found in the vegetal elements depicted in the barrel vault of Santa Maria della Croce. For the Neoplatonic philosophers and for the first Christian philosophers, further to the Gospel of John's prologue, the Logos is the mediator between God and the world, the guarantor of the communications between Heaven and Earth, because «all things were made by him and for him» as stated in the Niceno-Costantinopolitan Creed (325381 AD). For the philosopher Plotinus (204-270 AD), who reinterprets and expands Plato's thought (427-347 BC) the Logos is the emanation of the One. For Pythagoras (around 580-495 AD), the One corresponds to the arché, the principle that creates and unifies reality and originates multiplicity. Also for Parmenides (515-450 AD) and for the Eleatics, reality originates from the One: Being is One and indivisible, infinite, 
immutable, innate and eternal. It is and it cannot not be, in accordance with the principle of non-contradiction.

According to the aforementioned Heraclitus, Logos is the One, unchangeable but taking changeable forms: "all is One and One is all", laying the foundation first for stoicism and later for pantheism. For this reason, in the mosaic of Casaranello's presbytery the images portrayed convey a much wider meaning than the mere decorative use. Numerous grapes, a single vine. Numerous broad beans, a single pod (the three pods symbolise the Trinitarian doctrine). Numerous pine nuts in a single pine cone (it is not an artichoke, as it was believed so far, simply because at the time the artichoke was yet unknown, it did not grow spontaneously and was first cultivated in the 15 th century). Numerous flowers (again in the number of three), a single plant. Two pears on a single branch (a reference to the double nature - human and divine - of Christ).

According to Augustine of Hippo (354-430 AD), the One is Jesus Christ's God, the natural goal to which reason aims and in which the contrast between subject and object, thought and essence reconcile in a perfect union. Rebutting to Manichaeism, Augustine states that the One is the root of Love that for its very nature mends the tear caused by the original sin and reunites Man with God.

Given the above, also the animals depicted in the mosaic of Casaranello find a full explanation: the fish, the hare, the cockerel and the pullet, the ducks and the dove. The fish recurs in the Christian symbology since the 2 nd century. The evangelic reference is the call of the first Apostles by Jesus, who asks them to follow him and become fishers of men, but the reference is also to the miraculous fishing, the multiplication of the bread and the fish and the lunch of the Risen appeared on the Lake Tiberias' shores. For Clemens of Alexandria (150-215 AD) the fish is the symbol of baptism and for Tertullian (160-220 AD) those who are baptised are «pisciculi», whose life depends on being immerged in the water of the baptism. He reiterates the Christological meaning of the acrostic of the word fish in Greek (ichtys): Iesoùs Christòs Theoù Yiòs Sotèr («Gesus Christ Son of God Saviour») (John 17, 20-23).

The image of the hare eating the grape can be found on many Roman sarcophagus with a Dionysian thematic, on others decorated with hunting scenes and others focused on autumn, commissioned in the Tetrarchy Age (between the end of the $3 \mathrm{rd}$ and the beginning of the 4 th century AD) by patricians with a fancy to Christianity. For its nature, the hare symbolises the fear and the run, becoming an allegory of the believer that - fearing to fall into the jaws of death - avoids temptations and escapes from its pitfalls. The hare's pause is soothed with a tasty grape, symbolising the Christian with the Eucharist. Mostly active at dawn and twilight, moments that for the ancients could open access to ultra terrestrial worlds, the hare also symbolises the initiation of the Christian getting in contact with the Divine.

Also the cockerel and the pullet, with their scratching and pitching, symbolise the Christian's quest for truth. For this reason, during the Middle Ages they represented the alchemists and the search for the philosopher's stone and perfect knowledge. The male and female ducks in the baptismal font also symbolise the baptismal initiation: they are migratory birds that every year undergo a long journey (comparable to the spiritual experience of the believer and the cycle of the seasons).

The same meaning is concealed in the image of the dove that Noah often let fly out of the Ark, after the Flood, to look for a land (Gen 8, 8-12).

\section{Per Aspera Ad Astra}

According to Aristotle and to Plato beforehand, multiplicity is only a transitional aspect of reality, because the essence of entities is characterised by unicity. The primacy of the One is uncontested, placed at the top as unmoved mover, the one causing the motion of the organisms and allowing them to pass from power to action.

In Casaranello's cupola, the Aristotelian unmoved mover coincides with the Christ's Cross. It is the Latin golden cross, with no gems, similar to the one standing out in the starry sky of the Mausoleum of Galla Placida (5th century) in Ravenna. The Cross is the peak of knowledge, the point of arrival and convergence of every quest for truth. Paul the Apostle gives the most suitable comment to this choice of iconology and faith: "For Jews demand signs and Greeks seek wisdom, but we preach Christ crucified a stumbling block to Jews and folly to Gentiles, but to those who are called, both Jews and Greeks, Christ the power of God and the wisdom of God. For the foolishness of God is wiser than men, and the weakness of God is stronger than men". (1 Cor 1, 22-25). It is most probably from this prominent element in the mosaic of Casaranello that the name "Madonna della Croce" originated.

The starry sky in the cupola is a depiction of the universe according to the Aristotelian-Ptolemaic system, which was improved by the astronomer Ptolemy of Alexandria in the 2 nd century $\mathrm{AD}$ and considered valid until the Copernican revolution (1543). According to the geocentric theory, the earth was at the centre of the universe, surrounded by nine skies: the ones of the Moon, Mercury, Venus, Sun, Mars, Jupiter, Saturn, the light-blue one of the so-called fixed stars and the first mobile. The Cross, unmoved mover governing the Cosmos from the Empyrean, is painted in golden on a blue sky.

\section{Conclusion}

Casaranello's mosaic, therefore, represents the journey undertaken by the soul to transcend and reach God, after freeing itself from the chains of materiality and healing from all kind of schizophrenia. An itinerary - quoting Dante eight centuries later - through the dark wood of corporeity up to «seeing the stars» (Divine Commedy, Hell, XXXIV, 139). A journey of purification through images which make better even us, viewers of the 2000s, up to the point that we can state, by quoting Immanuel Kant: «the starry sky above me and the moral law within me» (Critic of Pratical Reason, 1781). 


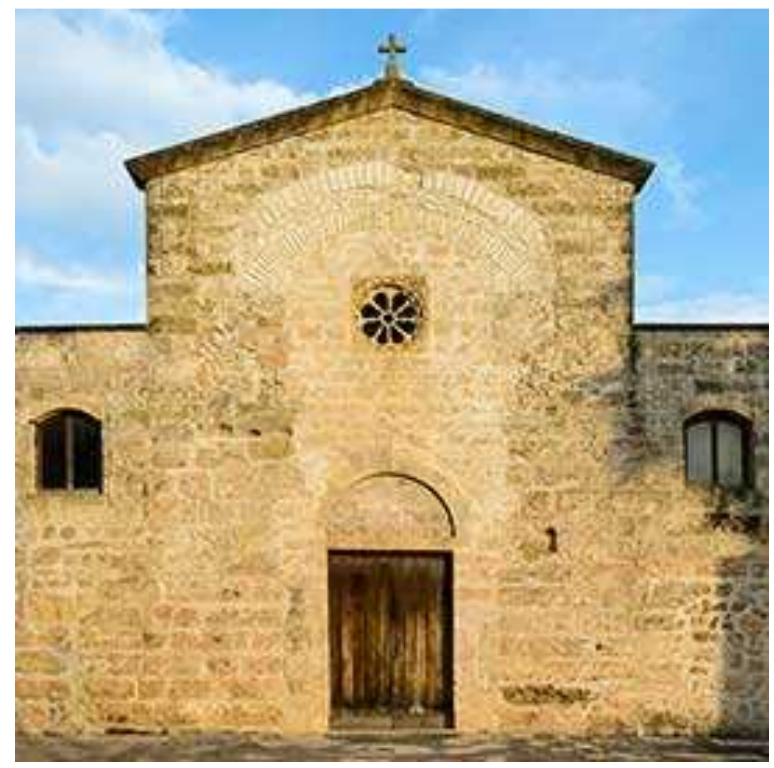

Figure 1. Church of Casaranello, facade.

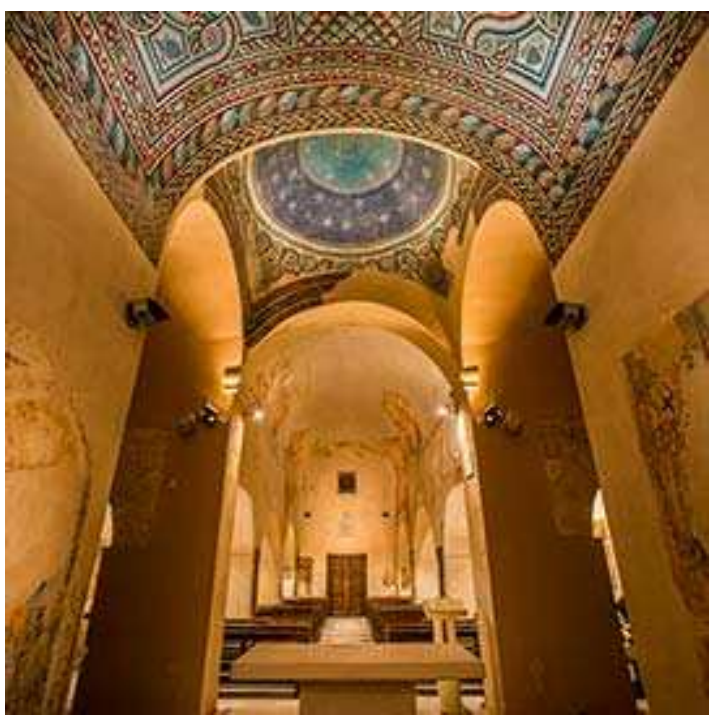

Figure 2. Casaranello, nave.

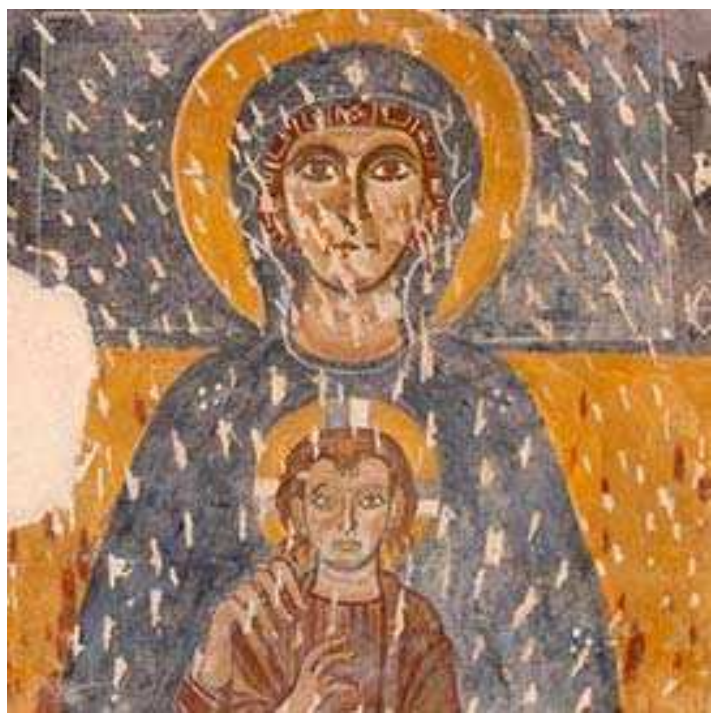

Figure 3. Casaranello, Theotokos, fresco.

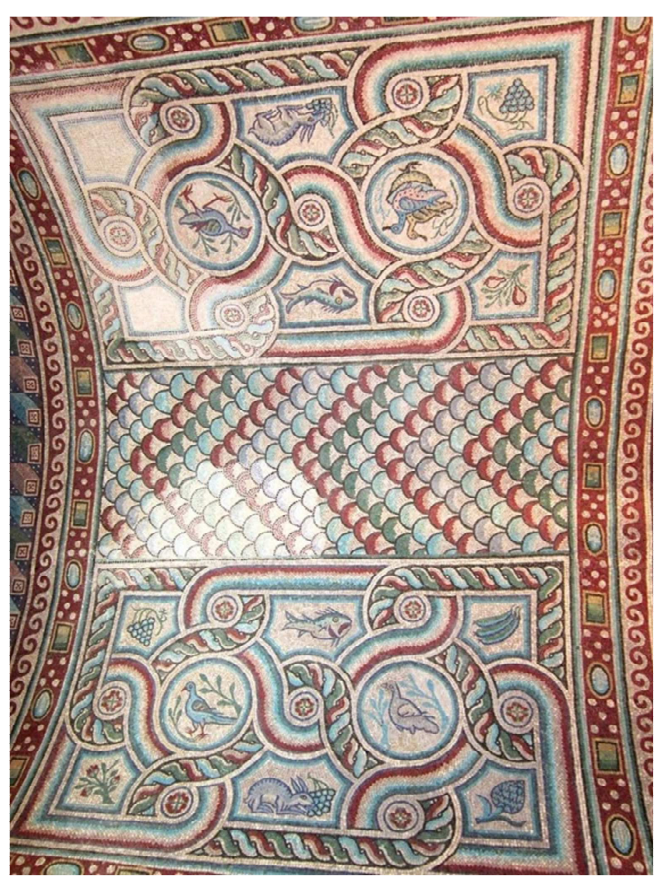

Figure 4. Casaranello, mosaic of the barrel vault.

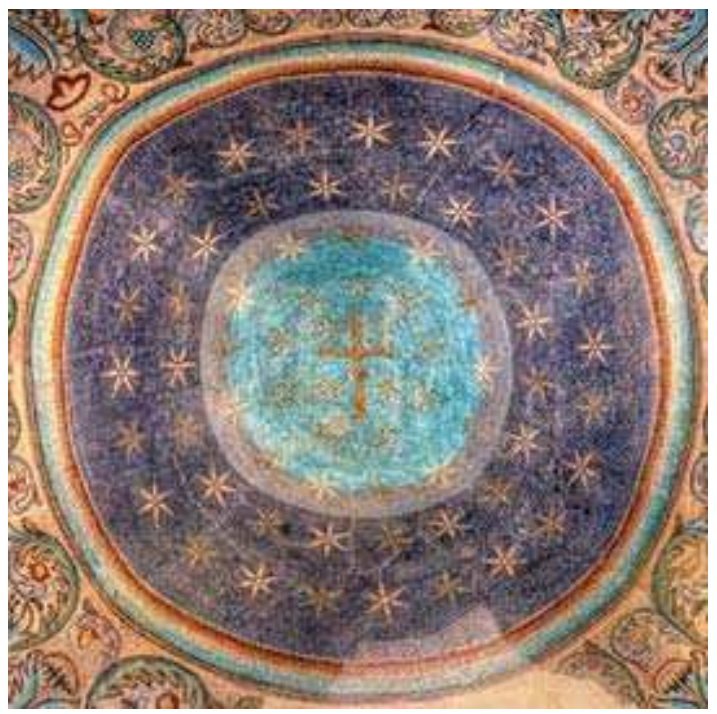

Figure 5. Casaranello, mosaic of the dome.

\section{References}

[1] Tasselli, L., Antichità di Leuca città già posta nel Capo Salentino. De' luoghi, delle terre, e d'altre Città del medesimo Promontorio, Eredi di Pietro Micheli, Lecce, 1693.

[2] Giustiniani, L., Dizionario geografico ragionato del Regno di Napoli, t. III, presso Vincenzo Manfredi, Napoli, 1797.

[3] Zuccagni Orlandini, A., Corografia fisica, storica e statistica dell'Italia e delle sue isole, supplement to vol. XI, Tipografia e calcografia all'insegna di Clio, Firenze, 1845.

[4] Arditi G., Corografia fisica e storica della Provincia di Terra d'Otranto, Scipione Ammirato, Lecce, 1879.

[5] De Giorgi, C., La Provincia di Lecce. Bozzetti di viaggio, 2 voll., Spacciante, Lecce, 1882-1888. 
[6] Giordano, O., La guerra greco-gotica nel Salento, in «Brundisii res», VI (1974), pp. 49-77.

[7] Uggeri, G., La viabilità romana nel Salento, Schena, Fasano, 1983; Chetry, A., Spigolature casaranesi, 1-6, edited by G. Pisanò, Casarano, Carra, 1990.

[8] Carducci, L., Storia del Salento, vol. 1, La Terra d'Otranto dalle origini ai primi del Cinquecento. Società religione economia cultura, Congedo, Galatina, 1993.

[9] Seclì, O., Storie e genealogie di Terra d'Otranto: Casarano grande e piccola, Il Laboratorio, Parabita, 1999.

[10] Martinelli, C., Da Specchia di Vaje a Casarano. Ragionamento sulle origini di Casarano motivato dalla toponomastica rurale, Edizioni Esperidi, Monteroni, 2017.

[11] D' Angela, C., La tradizione petrina in Puglia, Adriatica, Bari, 1976.

[12] Id., Note sull'introduzione del cristianesimo nel Basso Salento, in Palese, S., (Ed.) Il Basso Salento. Ricerche di storia sociale e religiosa, Congedo, Galatina, 1982.

[13] Fonseca, C. D., Particolarismo istituzionale e organizzazione ecclesiastica delle campagne nell'Alto Medioevo nell'Italia Meridionale, in Atti della XXVIII Settimana di Studi sull'Alto Medioevo, Centro Italiano di Studi sull'Alto Medioevo, Spoleto, 1982, pp. 1163-1200.

[14] Palese, S., Diffusione del cristianesimo in Puglia. Appunti, VivereIn, Roma-Monopoli, 1983.

[15] Otranto, G., Italia Meridionale e Puglia Paleocristiane. Saggi storici, Edipuglia, Bari, 1991.

[16] Quacquarelli, A., Spigolature paleocristiane nel Salento, in Volpe, G., (Ed.), Puglia paleocristiana e altomedievale, VI, Edipuglia, Bari, 1991, pp. 85-112.

[17] Papagna, A., Il cristianesimo in Puglia fino all'avvento dei Normanni (1071), Levante, Bari, 1993.

[18] Sirago, V. A., Puglia romana, Edipuglia, Bari, 1993; Volpe, G., Contadini, pastori e mercanti nell'Apulia tardo antica, Edipuglia, Bari, 1996.

[19] Fiocchi Nicolai, V. -Volpe, G., Aspetti della cristianizzazione degli agglomerati secondari, in Carra Bonacasa, R. M. Vitale, E. (Ed.), La cristianizzazione in Italia tra Tardoantico e Altomedioevo. Atti del IX Congresso Nazionale di Archeologia Cristiana, Agrigento 20-25 novembre 2004, vol. I, Carlo Saladino, Palermo, 2007, pp. 85-133.

[20] Danieli, F., Nardò-Gallipoli, in Palese, S. - de Palma, L. M (Ed.), Storia delle chiese di Puglia, Ecumenica Editrice, Bari, 2008.

[21] Danieli, F., Le origini del Cristianesimo in Terra d'Otranto, in «Cultura Salentina. Rivista di pensiero e cultura meridionale», May 24, 2013.

[22] De Grüneisen, W., Studi iconografici comparativi sulle pitture medievali romane. Il cielo nella concezione religiosa ed artistica dell'alto medioevo, in «Archivio della Società Romana di Storia Patria», XXIX, 3-4 (1906), pp. 443-526.

[23] Haseloff, A., I musaici di Casaranello, in «Bollettino d'Arte del Ministero della Pubblica Istruzione», I, 1 (1907), pp. 2227.
[24] Bartoccini, R., Casaranello e i suoi mosaici, in «Felix Ravenna», XLV, 3 (1934), pp. 157-185.

[25] Palumbo, G., La basilica della Madonna della Croce in Casaranello (Lecce), in «Arte cristiana», XXXVII (1950), pp. 117-123.

[26] Trinci Cecchelli, M. M., I mosaici di Santa Maria della Croce a Casaranello, in «Vetera Christianorum», XI, 1 (1974), pp. 167-186.

[27] D'Andria, F., Relazione sui sondaggi eseguiti nella Chiesa della Madonna della Croce di Casaranello (Le) nei giorni 1516-17 novembre 1976, Università degli Studi, Facoltà di Lettere e Filosofia, Istituto di Archeologia e Storia Antica, Lecce, 1976.

[28] Bucci Morichi, C., Restauri in Puglia 1971-1983, vol. II, Chiesa di Santa Maria della Croce, Schena, Fasano, 1983.

[29] Jacob, A., La consecration de Santa Maria della Croce à Casaranello et l'ancien diocèse de Gallipoli, in «Rivista di studi bizantini e neoellenici», XXV (1988), pp. 147-163.

[30] Spinosa, G., S. Maria della Croce di Casaranello: analisi delle strutture architettoniche, in «Arte medievale», I (2002), pp. 149-163.

[31] Falla Castelfranchi, M., La chiesa di Santa Maria della Croce a Casaranello, in G. Bertelli (Ed), Puglia preromanica. Dal V secolo agli inizi dell'XI, Jaca Book, Milano, 2004, pp. 161176.

[32] Pisanò, G., S. Maria della Croce in Casarano. Vera catechesi con i mosaici, in «Famiglia Cristiana», n. 40 (2003), p. 140.

[33] Danieli, F., Casaranello e il suo mosaico. Per aspera ad astra, Esperidi, Monteroni di Lecce, 2018.

[34] Danieli, F., La chiesa di Casaranello da Haseloff agli ultimi studi: una lettura iconological del mosaico e l'identificazione di un affresco senza nome, in Forschung in ihrer Zeit. 125 Jahre Kunsthistorisches Institut der Christian-AlbrechtsUniversität zu Kiel, Herausgegeben von Beuckers, K. G. und Kuder, U., Kiel, Verlag Ludwig, 2020, pp. 219-233.

[35] De Marco, A., Santa Maria della Croce - Casaranello, archeologia di un'architettura. Per una nuova lettura dell'impianto originario di Casaranello, Ibidem, pp. 199-217.

[36] Stefàno, L., S. Maria della Croce (Casaranello). Oltre un secolo di studi su un monumento paleocristiano del Salento, Grifo, Lecce, 2018.

[37] Spedicato, M., review of F. Danieli, Casaranello e il suo mosaico. Per aspera ad astra, Monteroni di Lecce, Esperidi, 2018, in «L'Idomeneo», n. 29 (2020), pp. 306-307.

[38] De Marco, Santa Maria della Croce - Casaranello, archeologia di un'architettura, op. cit., in Danieli, F. - De Marco, A., Nuove ipotesi su Casaranello. L'edificio, il mosaico, gli affreschi, EUROM, Roma, 2020, pp. 19-49.

[39] Prandi, A., Pitture inedite di Casaranello, in «Rivista dell'Istituto Nazionale di Archeologia e Storia dell'Arte», X (1961), pp. 227-292.

[40] Milella Lovecchio, M., Frescanti dei secc. XIII-XV. Scene del Nuovo Testamento, della vita di Santa Caterina e Santa Margherita, Madonna con Bambino e figure di Santi. Casaranello (Le), Chiesa di Santa Maria della Croce, in Restauri in Puglia 1971-1981, Schena, Fasano, 1983, pp. 105-109. 
[41] Leone de Castris, P., Pittura del Duecento e del Trecento a Napoli e nel Meridione, in Castelnuovo, E. (Ed.), II Duecento e il Trecento (La pittura in Italia), Electa, Milano, 1986, pp. 461-512.

[42] Safran, L., Redating Some South Italian Frescoes: The First Layer at S. Pietro, Otranto, and the Earliest Paintings at S. Maria della Croce, Casaranello, in «Byzantion», IX (1990), pp. 307-330.

[43] Falla Castelfranchi, M., La pittura bizantina in Salento, in Vetere, B. (Ed.), Ad Ovest di Bisanzio. Il Salento medioevale. Atti del Seminario Internazionale di Studio (Martano, 29-30 aprile 1988), Congedo, Galatina, 1990.

[44] Ortese, S., Pittura tardogotica nel Salento, Congedo, Galatina, 2014.

[45] Curzi, G., Svevi o Angioini alla periferia di Bisanzio. Le storie di S. Caterina e S. Margherita sulla volta di Santa Maria della Croce a Casaranello, in «Arte medievale», VI (2016), pp. 173184.

[46] Danieli, La chiesa di Casaranello da Haseloff agli ultimi studi, op. cit., pp. 229-231; Danieli - De Marco, Nuove ipotesi su Casaranello, op. cit., pp. 64-82.

[47] Ripa, C., Della più che novissima Iconologia, per Donato Pasquardi, Padova, 1630.

[48] Portal, F., Les couleurs symboliques dans l'Antiquité, le Moyen Age et les Temps modernes, Treutel et Würtz, Parigi, 1837.

[49] Migne, J. P. (Ed.), Patrologiae Cursus Completus, Series Latina, 221 vol 1., Paris, 1844-1855.

[50] Migne, J. P. (Ed.), Patrologiae Cursus Completus, Series Graeca, 161 vol 1., Paris, 1857-1866.

[51] Alberto Magno, De animalibus libri XXVI, ed. Stadler, Münster, 1916-1920.

[52] Leonardi, C., Àmpelos, il simbolo della vite nell'arte pagana e paleocristiana, Edizioni Liturgiche, Roma, 1947.

[53] Réau, L., Iconographie de l'art chrétien, P. U. F., Paris, 19551959.

[54] Bialostocki, J., Iconografia e iconologia, in Enciclopedia Universale dell'Arte, VII, Istituto per La Collaborazione Culturale, Roma-Venezia, 1958, pp. 163-174.

[55] Wittkower, R., Allegoria e migrazione di simboli, Einaudi, Torino, 1960.

[56] Panofsky E., Il significato delle arti visive, Einaudi, Torino, 1962.

[57] Gombrich, H., Arte e illusione, Einaudi, Torino, 1965.

[58] Saxl, F., La storia delle immagini, Laterza, 1965.

[59] Panofsky, E., Studi di iconologia, Einaudi, Torino, 1975.

[60] Zambon, F. (Ed.), Il Fisiologo, Adelphi, Milano, 1975.

[61] Borghi Cedrini, L., Appunti per la lettura di un bestiario medievale. Il bestiario valdese, Giappichelli, Torino, 1976.

[62] Cecchini, N., Dizionario sinottico di iconologia, Patron, Bologna, 1976.
[63] Romano, M., Il bestiario moralizzato, Ricciardi, MilanoNapoli, 1978.

[64] Baxandall, M., Patterns of Intention: On the Historical Explanations of Pictures, Yale University Press, New Haven, 1985.

[65] Ginzburg, C., Miti, emblemi, spie. Morfologia e storia, Einaudi, Torino, 1987.

[66] Davy, M. M., Il simbolismo medievale, Edizioni Mediterranee, Roma, 1988.

[67] Caprettini, G. P., Simboli al bivio, Sellerio, Palermo, 1992.

[68] Biedermann, H., Il libro dei segni e dei simboli, Gruppo Editoriale Brancato, Siracusa, 1993.

[69] Gilles, R., Il simbolismo nell'arte religiosa, Ed. Arkeios, Roma, 1993.

[70] Holly, M. A., Iconografia e Iconologia, Jaca Book, Milano, 1993.

[71] Charbonneau-Lassay, L., Il Bestiario del Cristo. La misteriosa emblematica di Gesù Cristo, voll. I-II, Arkeios, Roma, 1994.

[72] Urech, E., Dizionario dei simboli cristiani, Arkeios, Roma, 1995.

[73] Cattabiani, A., Florario: miti, leggende e simboli di fiori e piante, Mondadori, 1996.

[74] Cirlot, J. E., Dizionario dei simboli. Come interpretare la natura e il valore dei simboli per comprenderne il significato nascosto, Milano, Eco-Gruppo Editoriale Armenia, 1996.

[75] L. Morini (Ed.), Bestiari medievali, Einaudi, Torino, 1996.

[76] Beigbeder, O., Lessico dei simboli medievali, Jaca Book, Milano, 1997.

[77] Thoumieu, M., Dizionario di iconografia romanica, Jaca Book, Milano, 1997.

[78] Cervellin, L., L'arte cristiana delle origini. Introduzione all'archeologia cristiana, Elledici, Leumann, 1998.

[79] De Champeaux, G., I simboli del Medioevo, Jaca Book, Milano, 1998.

[80] Mondin, B., Storia della metafisica, vol. 1, Edizioni Studio Domenicano, Bologna, 1998.

[81] Biedermann, H., Enciclopedia dei simboli, Garzanti, Milano, 1999.

[82] Chevalier, J. - Gheerbrant, A., Dizionario dei simboli, Rizzoli, Milano, 1999.

[83] Grossato, A. Il libro dei simboli, Mondadori, Milano, 1999.

[84] Maspero, F. - Granata, A., Bestiario medievale, Piemme, Casale Monferrato, 1999.

[85] Pavone, M. A. (Ed.), Modelli di lettura iconografica: Il panorama meridionale, Liguori, Napoli, 1999.

[86] Baltrusaitis, J., Medioevo fantastico, Adelphi, Milano, 2000.

[87] Bisconti, F., Temi di iconografia paleocristiana, Pontificio Istituto di Archeologia Cristiana, Città del Vaticano, 2000. 
[88] Cattabiani, A., Volario: simboli, miti e misteri degli esseri alati, Mondadori, Milano, 2000.

[89] Guernon, R., Simboli della scienza sacra, Adelphi, Milano, 2000.

[90] Pasquale, M., L'apologia della Parola: un'omelia impressa nel marmo e nel bronzo. Lettura iconologia del portale e della porta della Cattedrale di Trani, in «Rivista di Scienze Religiose», XV (2001), pp. 89-109.

[91] G. Pisanò, S. Maria della Croce in Casarano. Vera catechesi con i mosaici, in «Famiglia Cristiana», n. 40 (2003), p. 140.

[92] Dolz, M., Iconografia, iconologia, in AA. Vv., Iconografia e arte cristiana, San Paolo, Cinisello Balsamo, 2004, pp. 765-768.

[93] Reale, G., Storia della filosofia greca e romana, vol. 3, Bompiani, Milano, 2004.

[94] Valenziano, C., Simboli e simbolismo, in AA. Vv., Iconografia e arte cristiana, San Paolo, Cinisello Balsamo, 2004, pp. 12961301.

[95] Boncompagni, S., Il mondo dei simboli. Numeri, lettere e figure geometriche, Edizioni Mediterranee, Roma, 2006.

[96] Hautecoeur, L., Mistica e architettura. Il simbolismo del cerchio e della cupola, Bollati Boringhieri, Torino, 2006.

[97] Špidlík, T., Miscellanea II. Alle Fonti dell’Europa. In principio era l'arte, Lipa, Roma, 2006.

[98] Gaballo, M. - Danieli, F., Il mistero dei segni. Elementi di iconologia sacra nella Cattedrale di Nardò tra Medioevo ed età barocca, Congedo, Galatina, 2007.
[99] Jaffé, D., Il Talmud e le origini ebraiche del cristianesimo, Jaca Book, Milano, 2008.

[100] Ouaknin, M. A., Invito al Talmud, traduzione di R. Salvadori, Bollati Boringhieri, Torino, 2009.

[101] Warren, J., I presocratici, Einaudi, Torino, 2009.

[102] Nuzzo, D., Vite e uva nell'arte funeraria paleocristiana: la documentazione delle lastre incise di produzione romana, in Bisconti, F. - Braconi, M. (Ed.), Incisioni figurate della Tarda Antichità. Atti del Convegno (Roma, 22-23 marzo 2012), Pontificio Istituto di Archeologia Cristiana, Città del Vaticano, 2013, pp. 367-380.

\section{Biography}

Francesco Danieli (Nardò, 1981). He graduated in Theology from the Theological Faculty of Southern Italy in Naples (2004). In Rome, at the Pontifical Institute of Christian Archeology, he obtained a post-university degree in Archeology (2007); at the University of the Holy Cross, he obtained a license in Theology and a specialization in History (2008) and the PhD in Theology History (2010). For the Roman University Editions he is director of Gli Argonauti. Historian and iconologist of international fame, he has written dozens of volumes and has signed numerous appreciated contributions of a historical, artistic and theological nature. 